Article

\title{
Interaction of Thalassia testudinum Metabolites with Cytochrome P450 Enzymes and Its Effects on Benzo(a)pyrene-Induced Mutagenicity
}

\author{
Livan Delgado-Roche ${ }^{1,2,+}$, Rebeca Santes-Palacios ${ }^{3, \dagger}{ }^{,}$José A. Herrera ${ }^{4}$, Sandra L. Hernández ${ }^{5}$, \\ Mario Riera ${ }^{1}$, Miguel D. Fernández ${ }^{1}$, Fernando Mesta ${ }^{6}$, Gabino Garrido ${ }^{7} \mathbb{D}$, Idania Rodeiro ${ }^{1, * \mathbb{C}}$ \\ and Jesús Javier Espinosa-Aguirre ${ }^{5, *}$ \\ 1 Departamento de Farmacología, Instituto de Ciencias del Mar (ICIMAR), Loma 14, Alturas del Vedado, \\ Plaza de la Revolución, La Habana 10600, Cuba; ldelgado@liomont.com.mx (L.D.-R.); \\ mario@icimar.cu (M.R.); migueldavid@cebimar.cu (M.D.F.) \\ 2 Dirección Médica, Laboratorios Liomont S.A. de C.V., Carretera México-Toluca 5420, \\ Ciudad de México 05320, Mexico \\ 3 Laboratorio de Toxicología Genética, Instituto Nacional de Pediatría, Insurgentes Sur 3700, \\ Insurgentes Cuicuilco, Ciudad de México 04530, Mexico; rebeca.santes@inp.mx \\ 4 Instituto de Ciencia y Tecnología de Materiales (IMRE), Universidad de La Habana, Zapata y G, Vedado, \\ Plaza de la Revolución, La Habana 10400, Cuba; jose@imre.oc.uh.cu \\ 5 Departamento de Medicina Genómica y Toxicología Ambiental, Instituto de Investigaciones Biomédicas, \\ Universidad Nacional Autónoma de México (UNAM), Ciudad Universitaria, Ciudad de México 04510, \\ Mexico; slhernandez@biomedicas.unam.mx \\ 6 Escuela Nacional de Medicina y Homeopatía, Instituto Politécnico Nacional, \\ Guillermo Massieu Helguera 239, Ciudad de México 07320, Mexico; lmestac1800@alumno.ipn.mx \\ 7 Departamento de Ciencias Farmacéuticas, Facultad de Ciencias, Universidad Católica del Norte, \\ Angamos 0610, Antofagasta 1240000, Chile; gabino.garrido@ucn.cl \\ * Correspondence: idania.rodeiro@infomed.sld.cu (I.R.); jjea@iibiomedicas.unam.mx (J.J.E.-A.); \\ Tel.: +53-7-8819812 (I.R.); +52-556229214 (J.J.E.-A.) \\ + Both authors equally contributed to this work.
}

Received: 31 October 2020; Accepted: 17 November 2020; Published: 19 November 2020

\begin{abstract}
The aim of the present work was to evaluate the effects of Thalassia testudinum hydroethanolic extract, its polyphenolic fraction and thalassiolin B on the activity of phase I metabolizing enzymes as well as their antimutagenic effects. Spectrofluorometric techniques were used to evaluate the effect of tested products on rat and human CYP1A and CYP2B activity. The antimutagenic effect of tested products was evaluated in benzo[a]pyrene (BP)-induced mutagenicity assay by an Ames test. Finally, the antimutagenic effect of Thalassia testudinum $(100 \mathrm{mg} / \mathrm{kg})$ was assessed in BP-induced mutagenesis in mice. The tested products significantly $(p<0.05)$ inhibit rat CYP1A1 activity, acting as mixed-type inhibitors of rat CYP1A1 $(\mathrm{Ki}=54.16 \pm 9.09 \mu \mathrm{g} / \mathrm{mL}, 5.96 \pm 1.55 \mu \mathrm{g} / \mathrm{mL}$ and $3.05 \pm 0.89 \mu \mathrm{g} / \mathrm{mL}$, respectively). Inhibition of human CYP1A1 was also observed $(\mathrm{Ki}=197.1 \pm 63.40 \mu \mathrm{g} / \mathrm{mL}$ and $203.10 \pm 17.29 \mu \mathrm{g} / \mathrm{mL}$ for the polyphenolic fraction and for thalassiolin B, respectively). In addition, the evaluated products significantly inhibit $(p<0.05)$ BP-induced mutagenicity in vitro. Furthermore, oral doses of Thalassia testudinum $(100 \mathrm{mg} / \mathrm{kg})$ significantly reduced $(p<0.05)$ the BP-induced micronuclei and oxidative damage, together with an increase of reduced glutathione, in mice. In summary, Thalassia testudinum metabolites exhibit antigenotoxic activity mediated, at least, by the inhibition of CYP1A1-mediated BP biotransformation, arresting the oxidative and mutagenic damage. Thus, the metabolites of $T$. testudinum may represent a potential source of chemopreventive compounds for the adjuvant therapy of cancer.
\end{abstract}

Keywords: Thalassia testudinum; thalassiolin B; polyphenols; CYP1A1; benzo[a]pyrene; chemoprevention 


\section{Introduction}

Air pollution-related diseases represent a major environmental problem affecting health worldwide. Outdoor and indoor pollution has been tightly associated with the incidence of respiratory diseases, including lung cancer. In accordance with WHO estimates, lung cancer causes about $6 \%$ of premature deaths related to outdoor air pollution, as well as tobacco consumption [1]. Polycyclic aromatic hydrocarbons (PAHs) are pollutants widely distributed in the environment as a result of organic matter incomplete combustion. Furthermore, PAHs are present in commercial products consumed by humans (e.g., tobacco) [2]. Benzo[a]pyrene (BP), one of the main PAH air pollutants, is metabolized by CYP1A1 and CYP1B1 enzymes and it is biotransformed into carcinogenic ( \pm )-B[a]P-r-7, t-8-dihydrodiol-t-9,10 (BPDE) epoxide species [2,3]. BPDE reacts with DNA to produce BPDE-N2-deoxyguanosine adducts, promoting DNA mutations and carcinogenesis [4-7]. The presence of BPDE-DNA adducts in human lung cells has been well documented to be related to the initiation of pulmonary cancer $[5,8]$.

Advances in the pharmaceutical industry improve cancer treatment; however, the discovery of new effective chemopreventive agents is still necessary. Cancer chemoprevention by natural or synthetic agents capable of avoiding, reversing or suppressing carcinogenic progression has become a plausible strategy to arrest cancer mortality [9]. There are several classes of cancer chemopreventive agents including blocking agents, which act at the initiation stage of carcinogenesis by inhibiting pro-carcinogen activating enzymes by inducing carcinogen-detoxifying enzymes, by enhancing antioxidant activity or by inducing DNA repair enzymes [10]. Cytochrome P450 (CYP450) enzymes are a superfamily of hemoproteins that catalyze the biotransformation of not only a wide array of drugs and endogenous substances, but also the bioactivation of many pro-carcinogens [11]. Consequently, specific CYP enzymes have been identified as potential targets for cancer chemoprevention [12].

Polyphenols exert a wide range of beneficial effects beyond their antioxidant and anti-inflammatory properties [13-15]. Data evidence from in vitro [16-20] and in vivo studies [21-24] suggest the chemoprotective role of polyphenols against lung carcinogenesis probably resulting from three main mechanisms: antioxidant activity, regulation of phase I and II enzymes and regulation of cell survival pathways [24].

Marine plants are a potential source of secondary metabolites with beneficial properties [25-32]. Thalassia testudinum seagrass grows abundantly in the Caribbean Sea, particularly in the Cuban coasts. A previous study reports sulfated glycoside flavone thalassiolin B (TB) (chrysoeriol7- $\beta$ D-glucopyranosyl-2"-sulphate, Figure 1) as the most abundant bioactive component within the T. testudinum crude hydroethanolic extract (Th) [33]. Other phenolic compounds have been identified in the extract, including apigenin-7-O- $\beta$-D-glucopyranosyl-2" ${ }^{\prime \prime}$-sulfate (thalassiolin C), chrysoeriol-7-O$\beta$-D-glucopyranoside, apigenin-7-O- $\beta$-D-glucopyranoside, dihydroxy-3' $4^{\prime}$-dimethoxyflavone 7-O$\beta$-D-glucopyranoside, luteolin- $3^{\prime}$-sulphate, chrysoeriol and apigenin [34]. Th shows in vitro scavenger activity for ${ }^{\bullet} \mathrm{OH}, \mathrm{RO}_{2}{ }^{\bullet}, \mathrm{O}_{2}{ }^{\bullet-}$ and $\mathrm{DPPH}^{\bullet}$ free radicals and in vivo antioxidant effects against brain and liver induced-lipid peroxidation in mice [34,35]. In addition, Th shows acute anti-inflammatory effects in mice [36] and it displays selective anti-proliferative activity against cancer cells compared to normal cells [37]. Besides, the extract also inhibits drug efflux by ABCG2/breast cancer resistance protein (BCRP) and $\mathrm{ABCB} 1 / \mathrm{P}$-glycoprotein (MDR1 gene), increasing intracellular accumulation of anticancer agents $[38,39]$. Thus, the marine angiosperm $T$. testudinum has been considered a natural source of potential antitumor agents.

On the other hand, Th modulates the activity of different isoforms of P450 system, including CYP1A and 2B families [38,40]; however, these interactions are not well characterized yet. As CYP1A and 2B subfamilies are involved in the metabolism of several mutagens and carcinogens, the enzymatic inhibition could be associated with decreased carcinogenic risk. Thus, the aim of the present work was to further characterize the effects of $T$. testudinum extract and its polyphenolic components (polyphenolic fraction of the hydroethanolic extract, $\mathrm{PF}$ ) on CYP1A and CYP2B enzymatic activity, an also to evaluate the effects of Th on BP-induced mutagenicity. 


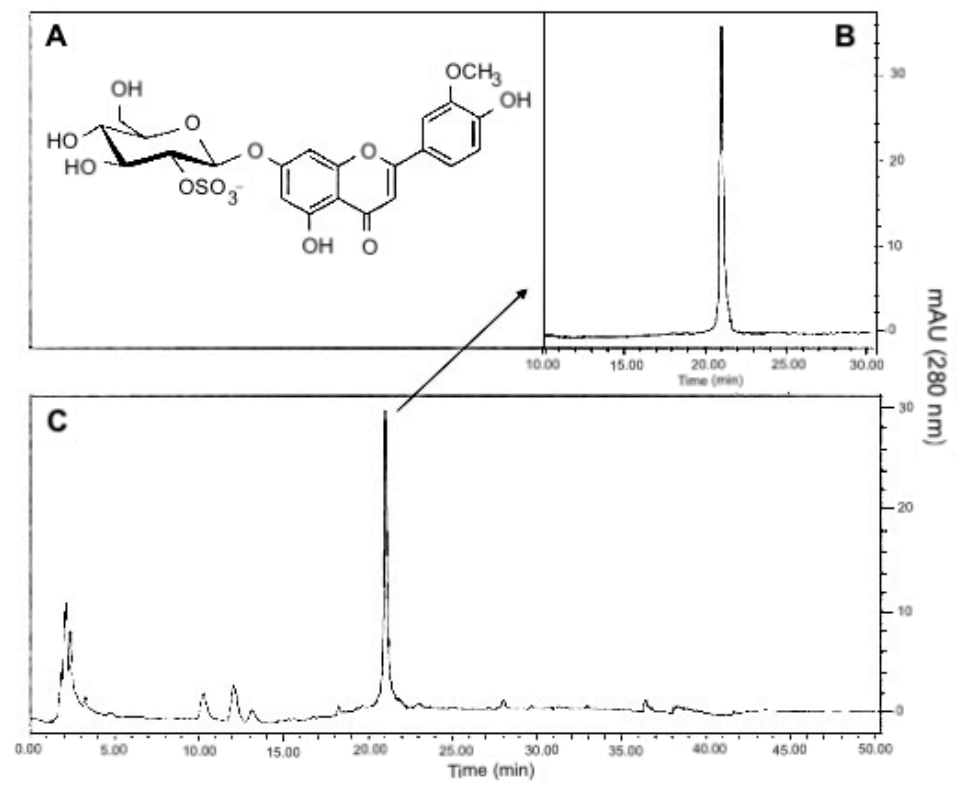

Figure 1. Chromatographic profile of thalassiolin B isolated from T. testudinum hydroethanolic extract. (A) Chemical structure of thalassiolin B (chrysoeriol 7- $\beta$-D-glucopyranosyl-2"-sulphate), the main component of T. testudinum extract. (B) HPLC of thalassiolin B standard. (C) HPLC profile of T. testudinum hydroethanolic extract. The authors have the right to use this figure.

\section{Results}

\subsection{Tested Compounds Modulate Rat CYP1A But Not CYPB2 Activity}

The enzymatic activity of CYP1A1/2 CYP2B1/2 was measured in rat liver microsomes in the presence, or not, of Th, PF or TB. Test products shown no interference with the fluorescence of resorufin even at the highest concentration tested. No appreciable changes in the activity of both CYP2B isoforms were observed (data not shown). In contrast, Th, PF and TB modulated the rat CYP1A activities as shown in Table 1. The enzymatic activity of both CYP1A1 and CYP1A2 was modulated by the test natural products; however, CYP1A1 was more sensitive than CYP1A2. The PF and TB showed a significant $(p<0.05)$ higher inhibitory effect than the crude extract (Th) on CYP1A isoforms; meanwhile, the Th showed no significant inhibition for CYP1A2.

Table 1. Rat CYP1A1/2 activity modulation by T. testudinum extract and its components.

\begin{tabular}{|c|c|c|c|c|c|c|}
\hline CYP & Product & & Test Pr & act Concentration & $(\mu \mathrm{g} / \mathrm{mL})$ & \\
\hline \multirow{4}{*}{ rCYP1A1 } & & 2.5 & 5.0 & 12.5 & 25.0 & 50.0 \\
\hline & Th & $74.88 \pm 2.92^{\mathrm{a}}$ & $63.11 \pm 8.22^{a, *}$ & $49.68 \pm 8.04^{\mathrm{a}, * *}$ & ND & ND \\
\hline & PF & $46.61 \pm 3.10^{b, * *}$ & $43.31 \pm 0.94^{b, * *}$ & $31.76 \pm 6.64^{b, * *}$ & $27.07 \pm 1.95^{\mathrm{a}, * *}$ & $24.00 \pm 2.97^{\mathrm{a}, * *}$ \\
\hline & TB & $53.83 \pm 1.08^{c, *}$ & $42.97 \pm 4.66^{b, * *}$ & $42.35 \pm 0.84^{a, * *}$ & $29.99 \pm 3.03^{a, * *}$ & $35.15 \pm 1.92^{b, * *}$ \\
\hline \multirow{4}{*}{ rCYP1A2 } & & 2.5 & 5.0 & 12.5 & 25.0 & 50.0 \\
\hline & Th & $100.47 \pm 10.66^{a}$ & $99.88 \pm 5.25^{\mathrm{a}}$ & $94.65 \pm 14.80^{\mathrm{a}}$ & ND & ND \\
\hline & PF & $83.93 \pm 2.55^{\mathrm{a}}$ & $71.87 \pm 2.85^{b}$ & $62.05 \pm 4.92^{b, *}$ & $55.02 \pm 2.84^{a, *}$ & $56.02 \pm 2.04^{\mathrm{a}, *}$ \\
\hline & TB & $81.01 \pm 8.06^{a}$ & $75.04 \pm 2.78^{b}$ & $57.08 \pm 4.70^{b, *}$ & $63.36 \pm 4.90^{\mathrm{a}, *}$ & $57.03 \pm 4.07^{\mathrm{a}, *}$ \\
\hline
\end{tabular}

Test products were added at $2.5-50.0 \mu \mathrm{g} / \mathrm{mL}$ to the incubation mixture containing rat liver microsomes $(80 \mu \mathrm{g})$ and 7-ethoxyresorufin $(1 \mu \mathrm{M})$ for CYP1A1 or 7-methoxyresorufin $(5 \mu \mathrm{M})$ for CYP1A2. The values represented the means \pm SD of CYP activities (\% respect control) from three independent experiments. Each sample was running by triplicate. The enzymatic activity in absence of test products was taken as 100\%. rCYP1A1, rCYP1A2: rat CYPs; Th: T. testudinum extract; PF: polyphenolic fraction; TB: thalassiolin B. Different letters $\left({ }^{a, b, c}\right)$ represent statistical differences $(p<0.05)$ between test products; ${ }^{*} p<0.05$, ${ }^{* *} p<0.01$ when compared with control $(100 \%$ enzyme activity). 


\subsection{T. testudinum Extract, Polyphenolic Fraction and Thalassiolin B Are CYP1A1 Mixed-Type Inhibitors}

Once CYP1A1 was identified as the most sensitive enzyme, kinetics experiments were performed in order to elucidate the type of inhibition induced by PF and TB. Demethylation of EROD in the presence of rat liver microsomes showed typical Michaelis-Menten kinetics for evaluated products (Figure 2A-C). Using non-linear regression and a Lineweaver-Burk plot, it was determined that Th, PF and TB are mixed-type inhibitors for rat CYP1A1 (Figure 2D-F) with constants of inhibition (Ki) of $54.16 \pm 9.09 \mu \mathrm{g} / \mathrm{mL}, 5.96 \pm 1.55 \mu \mathrm{g} / \mathrm{mL}$ and $3.05 \pm 0.89 \mu \mathrm{g} / \mathrm{mL}$, respectively (Table 2). In a mixed-type inhibition model, affinity changes of the enzyme for the substrate in presence of an inhibitor is determined by the parameter alpha $(\alpha)$, which was $8.66 \pm 2.82$ for Th, $370.60 \pm 56.86$ for PF and $3.65 \pm 0.86$ for TB (Table 2).

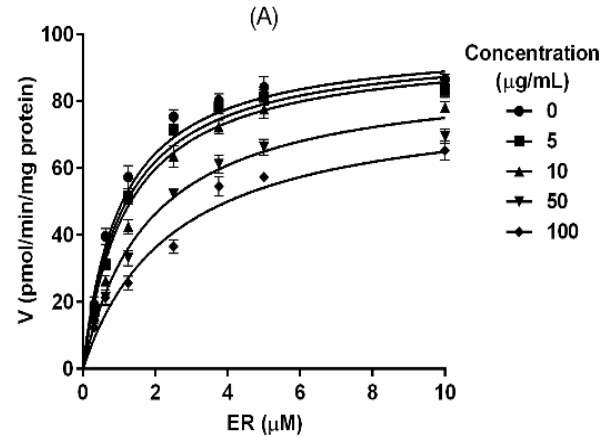

(B)

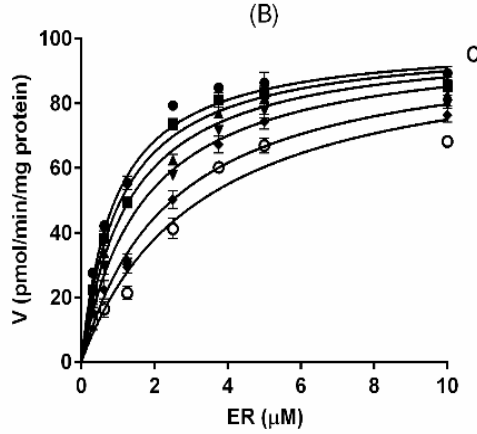

(C)

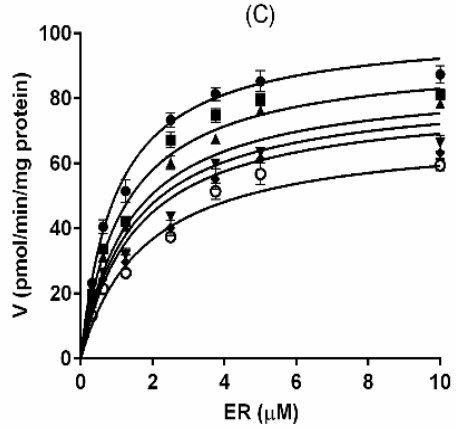

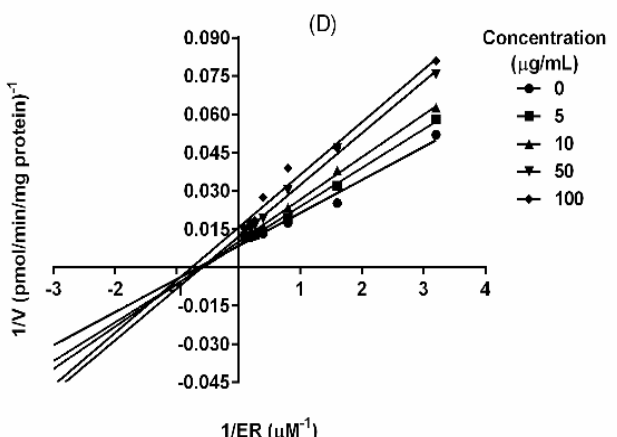

(E)

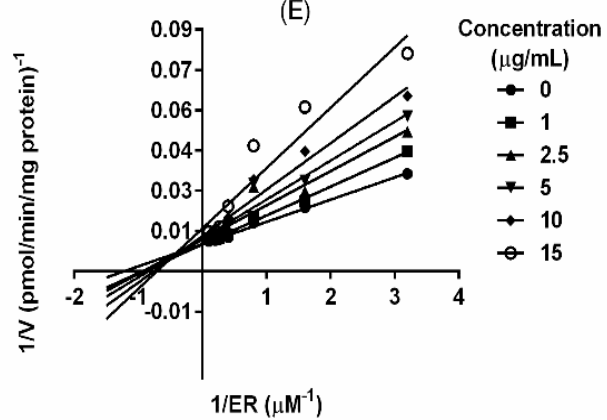

(F)

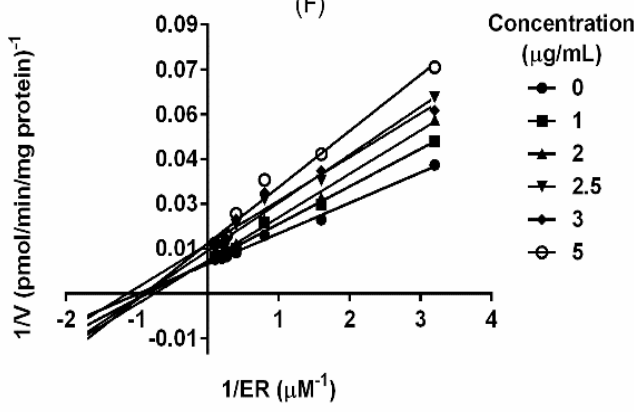

Figure 2. Inhibition kinetics of rat CYP1A1 by T. testudinum extract, polyphenolic fraction and Thalassiolin B. The fluorescence was recorded every $15 \mathrm{~s}$ during $15 \mathrm{~min}$; reactions consisted in $80 \mu \mathrm{g}$ protein, $0.32-10 \mu \mathrm{M}$ 7-ethoxyresorufin, and $50 \mathrm{mM}$ NADPH. For inhibition assays, the test products were added at different concentrations to the reaction mixture. Each point in $(\mathbf{A}-\mathbf{C})$ represents the mean \pm SD from three independent experiments. (D-F) Lineweaver-Burk plot analyses were done to obtain the kinetic parameters. (A,D) T. testudinum extract (Th); (B,E) polyphenolic fraction (PF); $(\mathrm{C}, \mathrm{F})$ thalassiolin B (TB). 
Table 2. Kinetics parameters for rat and human CYP1A1 inhibition.

\begin{tabular}{cccc}
\hline Inhibitor & Parameter & Rat CYP1A1 & Human CYP1A1 \\
\hline \multirow{2}{*}{ ER } & Vmax $(\mathrm{pmol} / \mathrm{min} / \mathrm{mgPr})$ & $2396.00 \pm 116.20$ & $95.20 \pm 8.14$ \\
& $\mathrm{Km}(\mu \mathrm{M})$ & $0.42 \pm 0.05$ & $0.34 \pm 0.02$ \\
\hline \multirow{2}{*}{ Th } & Type of inhibition & Mixed & - \\
& $\mathrm{Ki}(\mu \mathrm{g} / \mathrm{mL})$ & $54.16 \pm 9.09$ & - \\
& $\alpha$ & $8.66 \pm 2.82$ & - \\
\hline \multirow{2}{*}{ PF } & Type of inhibition & Mixed & Mixed \\
& $\mathrm{Ki}(\mu \mathrm{g} / \mathrm{mL})$ & $5.96 \pm 1.55$ & $197.10 \pm 63.40$ \\
& $\alpha$ & $370.60 \pm 56.86$ & $7.14 \pm 5.67$ \\
\hline \multirow{2}{*}{ TB } & Type of inhibition & Mixed & Non-competitive \\
& $\mathrm{Ki}(\mu \mathrm{g} / \mathrm{mL})$ & $3.05 \pm 0.89$ & $203.10 \pm 17.29$ \\
& $\alpha$ & $3.65 \pm 0.86$ & -
\end{tabular}

Data represent the mean $\pm \mathrm{SD}$ of three independent experiments. Kinetic parameters were obtained by a nonlinear regression analysis of experimental data fitted to Michaelis-Menten equation. EROD (7-ethoxyresorufin) was used as substrate, Vmax: maximum velocity, $\mathrm{Km}$ : Michaelis-Menten constant. Th: T. testudinum hydroethanolic extract; PF: polyphenolic fraction; TB: thalassiolin B. Human recombinant CYP1A1 was obtained from E. coli.

\subsection{Polyphenolic Fraction and Thalassiolin B Modulate the Human CYP1A1 Activity}

Taking into account that rat CYP1A1 was more sensitive than the CYP1A2 isoform, the effect of tested products on human recombinant CYP1A1 activity was evaluated. The results showed a significant $(p<0.05)$ inhibition of human recombinant CYP1A1 by PF and TB, while Th only exhibited a slight inhibitory effect on enzyme activity at the highest concentration (Figure 3A). The biochemical characterization of human CYP1A1 inhibition resulted in a mixed-type for PF and non-competitive inhibition for TB (Figure 3B-E). A moderate inhibitory potential was found for PF and TB on human CYP1A1 with Ki of $197.10 \pm 63.40 \mu \mathrm{g} / \mathrm{mL}$ and $203.10 \pm 17.29 \mu \mathrm{g} / \mathrm{mL}$, respectively (Table 2). These results showed a potential inhibitory effect of phase I carcinogen-metabolizing enzymes CYP1A1 by $T$. testudinum metabolites.
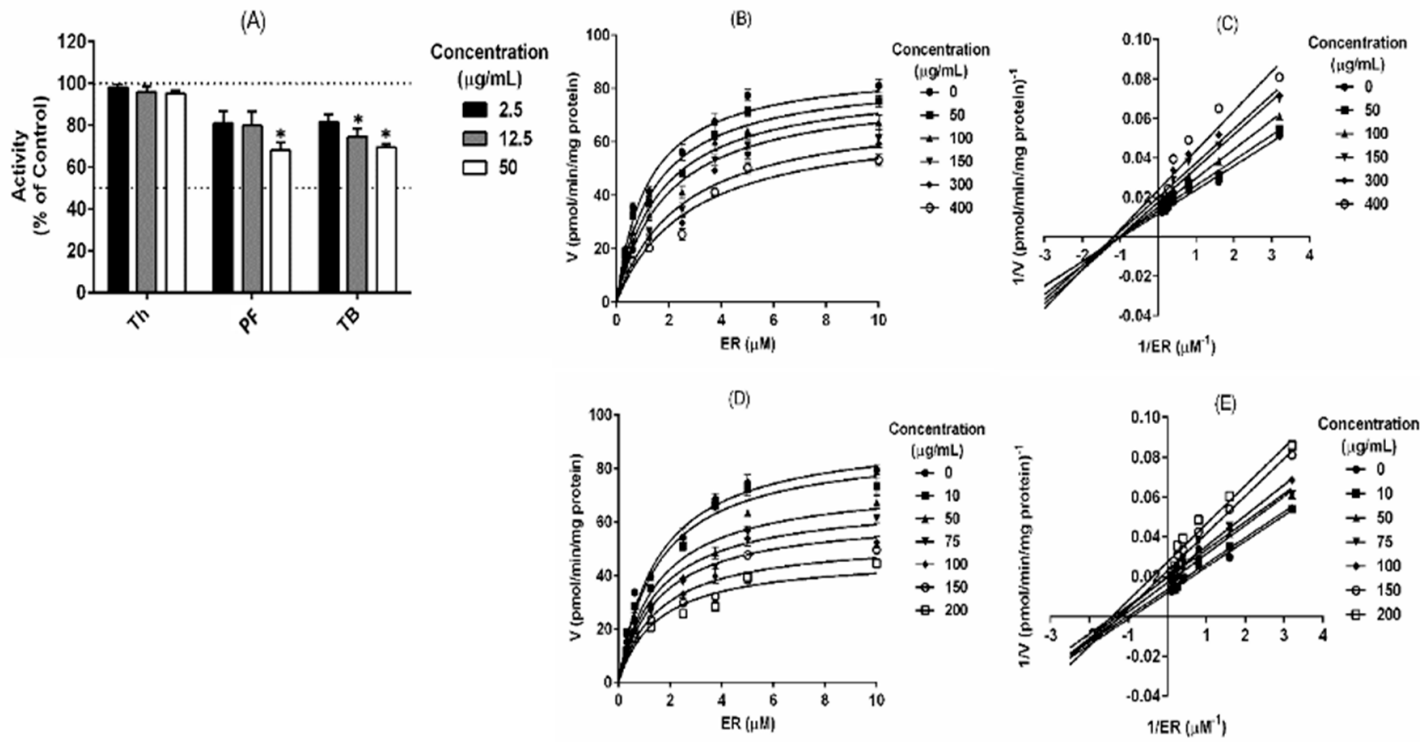

Figure 3. Inhibition of human recombinant CYP1A1 activity and kinetics by the tested products. (A) The fluorescence was recorded every $15 \mathrm{~s}$ during $15 \mathrm{~min}$; reactions consisted in $40 \mu \mathrm{g}$ protein, 0.32-10 $\mu \mathrm{M}$ 7-ethoxyresorufin, and $50 \mathrm{mM}$ NADPH. For inhibition assays, the products were added at different concentrations to the reaction mixture. Each point in (A) represents the mean \pm SD from three independent experiments. (B-E) Lineweaver-Burk plot analysis was done to obtain the kinetic parameters. (B,C) polyphenolic extract; (D,E) thalassiolin B. Th, Thalassia testudinum hydroethanolic extract; PF, polyphenolic fraction; TB, thalassiolin B. * Statistical differences $(p<0.05)$. 
2.4. Antimutagenic Effect of T. testudinum Extract, Polyphenolic Fraction and Thalassiolin B against Benzo[a]pyrene-Induced Mutagenicity in S. typhimurium

The bioactivation of BP by CYP1A1 leads to carcinogenic effects [2,5]. Since Th, PF and TB exert inhibitory effects on both rat and human CYP1A1 activity, we explored the potential anti-mutagenic effect of these compounds by using the Ames test. First, we evaluate the cytotoxicity of test products (up to $1000 \mu \mathrm{g} / \mathrm{mL}$ ) on $S$. typhimurium. The frequency of spontaneous reversion in controls (S9 plus vehicle) did not differ from the historically controls of our laboratory for S. typhimurium. Therefore, the test products are not cytotoxic for S. typhimurium, whereas BP induced a significantly $(p<0.05)$ increase of revertant frequency. Interestingly, the number of revertant colonies decreased in a dose-dependent fashion in presence of test natural products. The inhibition percentage of BP-induced mutagenicity in presence of $\mathrm{S}_{9}$ activation mixture achieved $27 \%$ for the highest tested dose of the extract $(1000 \mu \mathrm{g} / \mathrm{mL}), 34 \%$ for PF $(500 \mu \mathrm{g} / \mathrm{mL})$ and 33\% for TB (400 $\mu \mathrm{g} / \mathrm{mL})$ (Table 3). These results suggested that Th, PF and TB possess antimutagenic effects under these experimental conditions.

Table 3. Effects of T. testudinum extract and its components on benzo[a]pyrene-induced mutagenicity in Salmonella typhimurium.

\begin{tabular}{cc}
\hline Treatments & $\begin{array}{c}\text { His }^{+} \text {Revertants/Plate } \\
\text { (\% Inhibition) }\end{array}$ \\
\hline $\mathrm{S}_{9}$-Control & $23.1 \pm 2.0$ \\
$\mathrm{~S}_{9}-$ Control vehicle $+\mathrm{BP}$ & $746.2 \pm 32.3$ \\
$\mathrm{~S}_{9}-\mathrm{Th}(10 \mu \mathrm{g} / \mathrm{mL})+\mathrm{BP}$ & $714.4 \pm 8.5$ \\
$\mathrm{~S}_{9}-\mathrm{Th}(100 \mu \mathrm{g} / \mathrm{mL})+\mathrm{BP}$ & $678.0 \pm 11.2^{* *}(10 \%)$ \\
$\mathrm{S}_{9}-\mathrm{Th}(1000 \mu \mathrm{g} / \mathrm{mL})+\mathrm{BP}$ & $547.4 \pm 5.9^{* * *}(27 \%)$ \\
$\mathrm{S}_{9}-\mathrm{PF}(5 \mu \mathrm{g} / \mathrm{mL})+\mathrm{BP}$ & $713.4 \pm 8.8$ \\
$\mathrm{~S}_{9}-\mathrm{PF}(50 \mu \mathrm{g} / \mathrm{mL})+\mathrm{BP}$ & $665.5 \pm 10.1^{* *}(11 \%)$ \\
$\mathrm{S}_{9}-\mathrm{PF}(500 \mu \mathrm{g} / \mathrm{mL})+\mathrm{BP}$ & $497.3 \pm 10.7^{* * *}(34 \%)$ \\
$\mathrm{S}_{9}-\mathrm{TB}(400 \mu \mathrm{g} / \mathrm{mL})+\mathrm{BP}$ & $512.1 \pm 28.4^{* * *}(32 \%)$ \\
\hline
\end{tabular}

Data represent mean \pm SD of histidine revertant colonies number in TA98 S. typhimurium strain of two independent experiments by triplicate. Incubations were in presence of rat liver microsomal mix (S9). Th: T. testudinum extract; PF: polyphenolic fraction; TB: thalassiolin B, BP: benzo[a]pyrene. ${ }^{* *} p<0.01,{ }^{* * *} p<0.001$, ANOVA followed by Tukey test, compared to control vehicle + BP. \%inhibition: percentage of inhibition number revertants/plate in regards to "S9-Control (vehicle) + BP" group, as (1-(colonies/plates with BP + product)/(colonies/plate with just BP)) $\times 100 \%$.

\subsection{T. testudinum Extract Reduces Oxidative Damage and Micronuclei Formation in BP-Exposed Mice}

The capacity of Th to reduce BP-induced oxidative damage in mice was evaluated by measuring the serum levels of malondialdehyde (MDA), advanced oxidation protein products (AOPP) and reduced glutathione (GSH). As we expect, in Th pre-treated mice, the levels of MDA and AOPP were significantly lower $(p<0.05)$ than in BP control animals. In accordance with the reduction of oxidative damage, GSH level was significantly increased $(p<0.05)$ in Th pre-treated animals (Table 4). Additionally, BP induced a significant micronuclei formation in bone marrow of BP-exposed animals compared to cells from control animals (vehicle). Meanwhile, in Th pre-treated mice it was found a significant reduction $(p<0.05)$ of micronuclei formation (Table 5). These results indicate a protective effect by the extract obtained from T. testudinum leaves against BP-induced DNA damage together with a modulation of systemic oxidative stress in mice. 
Table 4. Effects of T. testudinum extract pre-treatment on oxidative stress biomarkers in mice after exposure to benzo(a)pyrene.

\begin{tabular}{cccc}
\hline Treatment (mg/kg) & $\begin{array}{c}\text { MDA } \\
(\mu \mathrm{M} / \mathbf{m g P r})\end{array}$ & $\begin{array}{c}\text { AOPP } \\
(\mu \mathrm{M} \text { chloramines/mgPr) }\end{array}$ & $\begin{array}{c}\text { GSH } \\
(\mu \mathrm{M} / \mathbf{m g P r})\end{array}$ \\
\hline Control (vehicle) & $3.17 \pm 0.5$ & $7.41 \pm 1.3$ & $495.1 \pm 67.8$ \\
BP & $7.31 \pm 0.2^{\mathrm{a}}$ & $14.67 \pm 1.2^{\mathrm{a}}$ & $149.7 \pm 63.5^{\mathrm{a}}$ \\
Th + BP & $5.55 \pm 0.6^{\mathrm{b}}$ & $11.64 \pm 1.5^{\mathrm{b}}$ & $352.8 \pm 35.1^{\mathrm{b}}$ \\
\hline
\end{tabular}

Values are expressed as mean \pm SD (concentration per $\mathrm{mg}$ protein). ${ }^{a}$ significant difference regarding control,

${ }^{b}$ significant difference regarding to BP group. Control: animals received 7 daily oral doses of distilled water and one dose of oil (BP vehicle). Th: T. testudinum extract, BP: animals received $250 \mathrm{mg} / \mathrm{kg}$ benzo(a)pyrene, BP + T. testudinum: 7 days oral pre-treatment with $100 \mathrm{mg} / \mathrm{kg} \mathrm{T}$. testudinum extract before receiving BP dose. ANOVA-Dunnett post hoc-test, $p<0.05$. MDA: malondialdehyde, AOPP: advanced oxidation protein products, GSH: reduced glutathione.

Table 5. Effects of T. testudinum extract on benzo(a)pyrene-induced micronucleus in mice bone marrow.

\begin{tabular}{ccc}
\hline $\begin{array}{c}\text { Treatment } \\
(\mathbf{m g} / \mathbf{k g})\end{array}$ & PCE/NCE & MN/PCE \\
\hline Control (vehicle) & $1.8 \pm 0.26^{\mathrm{b}}$ & $4.0 \pm 0.7^{\mathrm{b}}$ \\
BP & $3.4 \pm 0.78^{\mathrm{a}}$ & $17.0 \pm 1.7^{\mathrm{a}}$ \\
Th + BP & $2.0 \pm 0.21^{\mathrm{b}}$ & $7.0 \pm 1.0^{\mathrm{a}, \mathrm{b}}$ \\
\hline
\end{tabular}

Values are expressed as mean \pm SD. MN: micronucleus, PCE: polychromatic erythrocytes, NCE: normochromatic erythrocytes (2000 cells/animal), Control: Animals received 7 daily oral doses of distilled water and one dose of oil (BP vehicle). Th: T. testudinum extract, BP: animals received $250 \mathrm{mg} / \mathrm{kg}$ of benzo(a)pyrene, BP + T. testudinum: 7 days' oral pre-treatment with $100 \mathrm{mg} / \mathrm{kg}$ T. testudinum extract before receiving BP dose, ${ }^{\text {a }}$ significant difference regarding control, ${ }^{\mathrm{b}}$ significant difference regarding to BP group. ANOVA-Dunnett post hoc-test, $p<0.05$.

\section{Discussion}

There is evidence on the inhibitory effects of plant-derived phenols in PAH-induced mutagenesis and carcinogenesis [41,42]. The antimutagenic and chemopreventive properties of polyphenols have been associated with modulation of CYP450-mediated metabolism of mutagens, as well as to the interaction with active mutagenic metabolites [43]. It has been suggested that flavones which contain free 5- and 7-hydroxyls are potent inhibitors of cytochrome CYP1Al/2 [44]. Therefore, they may be useful as chemopreventive agents against PAH-induced carcinogenesis. The extract obtained from the leaves of T. testudinum marine plant is rich in flavonoids and other polyphenols $(29.5 \% \pm 1.2 \%$ total polyphenols, proanthocyanidins $21.0 \% \pm 2.3 \%$, total flavonoids $4.6 \% \pm 0.2 \%$, expressed as g per $100 \mathrm{~g}$ of the dry extract, $\% w / w)$ suggesting a potential inhibitory capacity on CYPs enzymatic activity. Derivate of T. testudinum are under preclinical investigation as new nutraceutical with promising active pharmacological effects [45-47]. The T. testudinum extract constitutes a potential source of chemopreventive agents because of its effectiveness as anti-inflammatory and antioxidant, which has been demonstrated previously [33-35,45-47].

In an earlier report, we describe the inhibitory effects of the Th and TB on the CYP1A1 activity in human hepatocytes [38]. The current work was aimed to further understanding of the effects of Th, PF and TB on CYP1A activity. This work let us evaluate the role of polyphenolic constituents of the extract, as substances responsible of its bioactive properties, in particular on phase I metabolizing enzymes.

Reduced O-Dealkylation of 7-ethoxyresorufin and 7-methoxyresorufin demonstrated the capacity of tested products to inhibit rat and human CYP1A1/2 activities. The polyphenolic-rich fraction isolated from the extract and TB revealed to be more active than Th, which in part supported our early hypothesis. All the natural products showed a mixed-type inhibition on rat CYP1A1, describing typical Michaelis-Menten kinetics, meanwhile exhibiting a differential response on human CYP1A1. Th did not inhibit the human CYP1A1 isoform. However, the PF and TB showed relevant inhibitory effects with differences in their kinetics and inhibition mechanism. PF acted as a mixed-type inhibitor, while TB behaved as non-competitive inhibition kinetics. These results were in agreement with previous reports 
on interspecies differences regarding the inhibitory potency of natural compounds $[47,48]$ and also provided additional evidence on the interactions of polyphenols with CYP450 system.

Other naturally occurring polyphenolic compounds, such as galangin (3,5,7-trihydroxyflavone) and apigenin (5,7,4-trihydroxyflavone) also inhibit CYP1A1 and CYP1A2 activities [49]. Reported values of apparent $\mathrm{Ki}$ for the inhibition of CYP1A1by galangin is $0.015 \mu \mathrm{M}$ [50] and $0.32 \mu \mathrm{M}$ apigenin [51]. On the other hand, there are fewer reports regarding the inhibition of CYP1B1 catalytic activity by naturally occurring compounds than CYP1A1 and CYP1A2. In fact, the extract and its polyphenolic components did not modulate CYP2B family activity under our experimental conditions.

The capacity of polyphenols and flavonoids to inhibit CYP1A1/2 isoforms has been proposed as the main mechanism supporting the antimutagenic and chemopreventive activities of these natural compounds [52]. Metabolic activation from BP to BPDE is believed to be essential for the mutagenic and carcinogenic properties of this pollutant [53,54]. CYP1Al plays an important role in the biotransformation/activation of BP $[55,56]$. Thus, we assessed the antimutagenic properties of the extract and its derivate in S. typhimurium TA98 by the mutagenesis assay of Maron and Ames (1983) [57]. The aim of this assay was to explore the biological consequences of the CYP1A modulation by the tested products. BP bioactivation was achieved by phenobarbital-induced rat liver $\mathrm{S}_{9}$ fraction. It is widely accepted that the Ames assay is useful for correlating in vitro mutagenesis and in vivo carcinogenicity in animals and humans. Th, PF and TB exerted a protective effect against BP-induced mutagenicity in S. typhimurium, evidenced here by the reduction of $\mathrm{His}^{+}$revertant colonies per plate, which suggested a potential antimutagenic activity of this marine organism.

Interestingly, in a previous report we observed a significant increase in BP mutagenicity after incubation with $\mathrm{S}_{9}$ fractions obtained from rats, orally treated during 10 days with doses of 200 and $400 \mathrm{mg} / \mathrm{kg}$ of Th; however, mutant colonies were reduced at low evaluated doses ( $20 \mathrm{mg} / \mathrm{kg}$ ) [40]. We also reported a differential response of CYP1A1, 1.5-fold increase after treatment with $200 \mathrm{mg} / \mathrm{kg}$ of Th, a discrete increase at $400 \mathrm{mg} / \mathrm{kg}$ dose and no significant changes at the low dose of T. testudinum extract. Differences in CYP activity suggest that polyphenol concentration could be a critical factor mediating the interaction between T. testudinum extract and CYP1A1 activity or BP mutagenicity. The present work may support this hypothesis, since BP-induced DNA damage, micronucleus frequency and oxidative damage diminished in orally pre-treated mice with $100 \mathrm{mg} / \mathrm{kg}$ of Th. These results are in agreement with the in vitro Ames test results and contrast with previous reports of our group in which a high dose of Th was assessed.

Antioxidant and anti-inflammatory properties of T. testudinum extract have been also observed under similar experimental conditions [46,58]. Accordingly, T. testudinum extract could protect DNA by different mechanisms, where antioxidant effects and the modulation of BP bioactivation should be conjugated. The capacity of T. testudinum components to inhibit CYP1A enzymatic activity could certainly be involved in the observed chemoprotective effect, but the alternative hypothesis which considers that Th components may act as scavengers that bind reactive metabolites of BP must not be discarded (assessed in ongoing studies). Previously, we demonstrated that the extract protects rat hepatocytes from terbutil-hidroperoxide-induced GSH depletion, together with higher catalase and superoxide dismutase activities compared with controls [35]. Th also showed protective effects against ethanol-, carbon tetrachloride- and lipopolysaccharide-induced cytotoxicity in rat hepatocytes [35]. Therefore, it seems that a combination of different mechanisms might be involved in the complex interaction of T. testudinum extract and the ADME cellular process, which in turn has influence its bioactive properties.

DNA oxidative damage is critical for BP in vivo toxicity [59-61]. It has been also reported that BP induces genetic lesions such as DNA single-strand breaks, DNA-protein cross-links and chromosomal aberrations [60]. The protective effects of Th against acute exposure to BP were corroborated here by mean the micronucleus assay. As we expected, Th reduced not only the BP-oxidative damage but also the micronucleus formation, meanwhile an increase of antioxidant defenses, such as GSH levels, was observed. 
These results altogether support new findings on the modulation of CYP system and particularly CYP1A1 by T. testudinum polyphenols. As mentioned before, CYP1A1/2 activity plays a significant role in the activation/detoxification balance of pro-carcinogens in hepatic and extrahepatic tissues. Therefore, the inhibitory effects of polyphenols present in T. testudinum marine plant on CYP1A activity may explain, in part, the antimutagenic and/or chemopreventive properties of these natural products.

\section{Materials and Methods}

\subsection{Materials and Reagents}

Beta-naphtoflavone ( $\beta$-NF), 7-ethoxyresorufin (EROD), methoxyresorufin (MROD), benzyloxiresorufin (BROD), penthoxyresorufin (PROD), resorufin and benzo[a]pyrene (BP) were purchased from Sigma (St. Louis MO, USA). Culture media were obtained from BD Difco (Trenton, NJ, USA). The Escherichia coli DH5 $\alpha$ recombinant and Salmonella typhimurium strains were kindly provided by Dr. Peter Guengerich (Vanderbilt University, Nashville, TN, USA).

\subsection{Vegetal Material}

Thalassia testudinum (Banks and Soland ex. Koenig) was collected during March 2017 in "Guanabo" beach $\left(22^{\circ} 05^{\prime} 45^{\prime \prime} \mathrm{N}, 82^{\circ} 27^{\prime} 15^{\prime \prime} \mathrm{W}\right)$. The specimen was identified by Dr. J.A. Areces (Institute of Oceanology, Havana, Cuba) and a voucher sample (No. IdO40) is deposited in the herbarium of the Cuban National Aquarium. The leaves were washed with water to eliminate sediments and the excess of salt; then, the plant material was dried at room temperature. Whole dry and ground T. testudinum leaves $(840 \mathrm{~g})$ were continuously extracted with ethanol- $\mathrm{H}_{2} \mathrm{O}(50: 50, v / v)$ during $24 \mathrm{~h}$ at room temperature. The extract was filtered and concentrated under reduced pressure and temperature $\left(40^{\circ} \mathrm{C}\right)$ to yield $54 \mathrm{~g}$ of crude extract $(\mathrm{Th})$.

Th was used as a starting material to obtain a polyphenol-enriched fraction (PF), where non-polar components were excluded by chloroform extraction $(1: 10, \mathrm{w} / \mathrm{v})$. The resultant PF was filtered and dried at room temperature. Later, TB (1-chrysoeriol 7- $\beta$-D-glucopyranosyl-2"-sulphate) was isolated by electrospray ionization mass spectrometry (ESIMS) with an $[\mathrm{M}-\mathrm{H}]-$ ion at $\mathrm{m} / \mathrm{z}=541$. The structure was confirmed by spectroscopic analysis $\left({ }^{1} \mathrm{H}\right.$ and ${ }^{13} \mathrm{C}$ nuclear magnetic resonance) as shown in Figure 1 , and compared to reported data [38].

\subsection{Rat Liver $S 9$ and Microsomal Fraction Obtaining}

The S9 fraction was obtained as previously described [57]. To obtain the microsomal fraction, $\mathrm{S}_{9}$ was split into $1 \mathrm{~mL}$ aliquots and centrifuged at $100,000 \times \mathrm{g}$ and $4{ }^{\circ} \mathrm{C}$ per $60 \mathrm{~min}$. The pellet was resuspended in $0.1 \mathrm{M}$ phosphate buffer ( $\mathrm{pH} 7.4$ ) plus $0.25 \mathrm{M}$ sucrose and it was centrifuged again at $100,000 \times g$ at $4{ }^{\circ} \mathrm{C}$ per $60 \mathrm{~min}$. The pellet (microsomal fraction) was resuspended in $0.1 \mathrm{M}$ phosphate buffer (pH 7.4), $1 \mathrm{mM}$ EDTA, $0.1 \mathrm{mM}$ dithiothreitol and $20 \% \mathrm{v} / \mathrm{v}$ glycerol and stored at $-80^{\circ} \mathrm{C}$ until use.

\subsection{Bacterial Membrane Fraction Obtaining}

The isolation of membrane fractions from Escherichia coli expressing a recombinant human CYP1A1 was performed as previously described [62,63]. Briefly, overnight cultured E. coli DH5 $\alpha$ were diluted 1:100 in Terrific Broth/ampicillin $(100 \mu \mathrm{g} / \mathrm{mL})$ medium containing $1 \mathrm{mM}$ isopropyl b-D thiogalactoside, $0.5 \mathrm{mM}$ aminolevulinic acid, $1 \mathrm{mM}$ thiamine and trace salts. Bacteria cultures were grown during $24 \mathrm{~h}$ at $30^{\circ} \mathrm{C}$ and $150 \mathrm{rpm}$ shaking. Thereafter, E. coli membrane fractions were isolated from the whole pellets by serial d ultracentrifugation steps. 


\subsection{Enzymatic Activity Assays}

\subsubsection{CYP1A1 and CYP1A2 Activities}

CYP enzymatic activities were evaluated in rat liver microsomes and in bacterial membrane fraction by spectrofluorometric assay as previously described [48,64], with slight modifications. The reaction mixtures contained: rat liver microsomes $(80 \mu \mathrm{g})$ or bacterial membrane fraction $(40 \mu \mathrm{g})$, EROD $(1 \mu \mathrm{M})$ or MROD $(5 \mu \mathrm{M})$ substrate and 2.5 to $50 \mu \mathrm{g} / \mathrm{mL}$ of test products (Th, PF or TB). Then, buffer solution (Tris- $\mathrm{HCl}(50 \mathrm{mM})$ and $\mathrm{MgCl} 2(25 \mathrm{mM}), \mathrm{pH}=7.6)$ was added to reaction mixtures and incubated $3 \mathrm{~min}$ at $37^{\circ} \mathrm{C}$. The reaction started by the addition of NADPH $(0.5 \mathrm{mM})$. The fluorescence units were registered at $20 \mathrm{~s}$ intervals during $15 \mathrm{~min}$ in a hybrid multi-mode microplate reader (Synergy H4, Biotech). Finally, CYPs activities were calculated from a resorufin standard curve $(5-50 \mathrm{pmol} / \mathrm{mL})$. Interference of tested products with the fluorescence of resorufin was also carried out.

\subsubsection{CYP2B1 and CYP2B2 Activities}

The activities of CYP2B1-related penthoxyresorufin O-dealkylase (PROD) and CYP2B2-related benzyloxyresorufin O-dealkylase (BROD) were determined in rat liver microsomes by spectrofluorometric techniques as previously described [64], with minor modifications. The assays were conducted under similar conditions previously described for CYP1A activity.

\subsection{Kinetic Analysis of Enzyme Inhibition}

Different concentrations of substrates $(0.32-10 \mu \mathrm{M}$ of EROD) mixed with rat liver microsomes $(80 \mu \mathrm{g})$ or $E$. coli membrane fraction $(40 \mu \mathrm{g})$ were used for enzymatic kinetics assays in presence or absence of the tested products. Kinetic constants were obtained by a nonlinear regression analysis of experimental data fitted to the Michaelis-Menten equation with competitive, non-competitive and mixed-type inhibition models (GraphPad Prism version 6 software). Kinetic analysis was also shown by using the Lineweaver-Burk plot.

\subsection{Ames Test}

The effects of the tested products against BP-induced mutagenicity was assessed according to Maron and Ames [57], in Salmonella typhimurium strain TA98 and rat liver $\mathrm{S}_{9}$ fraction. The reaction mixture contained $0.6 \%$ agar, $0.5 \% \mathrm{NaCl}, 0.5 \mathrm{mM}$ biotin and $0.05 \mathrm{mM}$ L-histidine. A solution of the tested products $(100 \mu \mathrm{L}$ ) at different concentrations (Th: 10, 100, $1000 \mu \mathrm{g} / \mathrm{mL}$; PF: 5, 50, $500 \mu \mathrm{g} / \mathrm{mL}$; TB: $400 \mu \mathrm{g} / \mathrm{mL})$, overnight cultured S. typhimurium ( $10^{8}$ cells), S9 $(500 \mu \mathrm{L})$ and benzo(a)pyrene $(10 \mu \mathrm{g} / \mathrm{plate})$ were added to the reaction mixture $(2 \mathrm{~mL})$. Phosphate buffer $(500 \mu \mathrm{L})$ was used instead of the $\mathrm{S}_{9}$ fraction as negative control. Afterward, the plates were incubated at $37^{\circ} \mathrm{C}$ for $48 \mathrm{~h}$ and the number of revertant colonies (His+) was quantified. The inhibition percentage of BP-induced mutagenicity was calculated as (1-(number colonies/plates with mutagen plus the tested products)/(number colonies/plate with just mutagen) $) \times 100 \%$.

\subsection{Effects of the T. testudinum Extract against BP-Induced DNA Damage in Mice}

Balb/c male mice (20-25 g) were obtained from Centro para la Producción de Animales de Laboratorio (CENPALAB, Havana, Cuba). The animals were adapted to standard conditions (temperature: $20 \pm 2{ }^{\circ} \mathrm{C}$, humidity: 40-60\%, $12 \mathrm{~h}$ light/dark cycle) during a week. Mice were fed with a standard diet and water ad libitum. Experimental procedures were carried out in accordance with European regulations on animal protection (Directive 86/609), and the Guide for the Care and Use of Laboratory Animals as adopted and promulgated by the US National Institute of Health (NIH Publication № 85-23, revised 1996). The experimental protocol was approved by the Institutional Animal Care and Ethical Committee from the Institute of Marine Sciences (ICIMAR), Havana, Cuba (Protocol number 1805, Date of approval: 28 March 2018). Four groups were included 
in the study (five animals per group). The first group was animals received seven daily oral doses of distilled water and one dose of oil (BP vehicle). The second group only received one oral dose of benzo(a)pyrene $(250 \mathrm{mg} / \mathrm{kg})$, the last day of the experiment. The third group was orally treated with Th aqueous solution $(100 \mathrm{mg} / \mathrm{kg})$ for seven days and one hour after the last administration of the extract, animals received an oral dose of BP $(250 \mathrm{mg} / \mathrm{kg})$. After $24 \mathrm{~h}$, all the animals were sacrificed, and blood samples were obtained by cardiac puncture and centrifuged at $3000 \times g$ for $10 \mathrm{~min}$, at $4{ }^{\circ} \mathrm{C}$. Serum was collected and stored at $-80^{\circ} \mathrm{C}$ until use.

\subsubsection{Oxidative Stress Biomarkers Determination}

Serum markers of oxidative stress were determined in mice. Malondialdehyde (MDA) content was determined as previously described [65]. Reduced glutathione (GSH) levels were measured at $412 \mathrm{~nm}$ after precipitation of thiol proteins by using the Ellman's reagent (5,5'dithiobis-2-nitrobenzoic acid, Sigma, Burbank, CA, USA) in accordance with Sedlak and Lindsay [66]. The advanced oxidation protein products (AOPP) were quantified with potassium iodide $(1.16 \mathrm{M})$ followed by the addition of acetic acid. The absorbance was immediately read at $340 \mathrm{~nm}$. AOPP concentration was expressed as $\mu \mathrm{M}$ of chloramine-T. Concentration of oxidative stress biomarkers was expressed per mg of protein.

\subsubsection{Micronuclei Formation Determination}

After mice euthanasia, the femurs were removed, and its proximal end was shortened until the marrow canal became visible. One milliliter of serum was introduced into the bone canal and the marrow was aspirated and flushed several times. Cells were centrifuged at $1000 \mathrm{rpm}$ for $5 \mathrm{~min}$ at $4{ }^{\circ} \mathrm{C}$. Afterward, they were fixed in methanol and stained with Giemsa 5\% $(v / v)$ for $12 \mathrm{~min}$. The presence of micronuclei was determined in a sample of 2000 polychromatic erythrocytes (PCE). Normochromatic erythrocytes (NCE) were also scored in 200 erythrocytes samples to determine the PCE/NCE ratio [67].

\subsection{Statistical Analysis}

Statistical analyses were performed with GraphPad Prism 5.0 (GraphPad, La Jolla, CA, USA). Revertants/plate, enzymatic activities, MDA, GST, AOPP levels, and micronucleus data were expressed as mean \pm SD values. For multiple mean comparisons was used a one-way ANOVA followed by Dunnett or Tukey non-parametric tests. The level of statistical significance was set to ${ }^{*} p<0.05$, ** $p<0.01$, or ${ }^{* * *} p<0.001$.

\section{Conclusions}

In summary, our results suggest that in vitro and in vivo antimutagenicity effects of Thalassia testudinum extract and its polyphenolic components may be mediated, at least, by the inhibitory effect on phase I metabolizing enzymes, in particular the CYP1A family. As consequence, reduced oxidative stress and mutagenic effects were observed. The results altogether contribute to support the potential of $T$. testudinum as a source of chemoprotective compounds against air pollution-mediated carcinogenesis.

Author Contributions: J.J.E.-A., I.R., R.S.-P. and L.D.-R. were responsible for the general study concept, conducting experimental analysis, interpreting and discussing of results, and drafting the manuscript. L.D.-R., F.M., J.A.H., S.L.H., M.R., M.D.F. and G.G. contributed, analyzed and interpreted the chemical and biological experiments. J.J.E.-A., I.R., R.S.-P., L.D.-R. were responsible of discussing of results. F.M., R.S.-P., L.D.-R. carried out statistical data analysis. Funding acquisition: I.R., G.G., J.J.E.-A. and L.D.-R. All authors have read and agreed to the published version of the manuscript.

Funding: This research was funded by: CITMA P211LH005-019 (Cuba); the program Becas de Excelencia del Gobierno de México para Extranjeros 2016 (México); FONDECYT 1130601 (Chile), as well as Programas Institucionales del Instituto de Investigaciones Biomédicas, UNAM (México).

Acknowledgments: The authors acknowledge the technical support given by Cindel Cuellar. 
Conflicts of Interest: The authors declare no conflict of interest. The funders had no role in the design of the study; in the collection, analyses or interpretation of data; in the writing of the manuscript or in the decision to publish the results.

\section{References}

1. World Health Organization. 7 Million Premature Deaths Annually Linked to Air Pollution. Available online: https://www.who.int/mediacentre/news/releases/2014/air-pollution/en/\#: \{\}:text=25\%20March\%202014\% 20\%7C\%20Geneva\%20\%2D\%20In,result\%20of\%20air\%20pollution\%20exposure (accessed on 24 March 2020).

2. Kim, J.H.; Stansbury, K.H.; Trush, M.A.; Strickland, P.T.; Sutter, T.R. Metabolism of benzo[a]pyrene and benzo[a]pyrene-7,8-diol by human cytochrome P450 1B1. Carcinogenesis 1998, 19, 1847-1853. [CrossRef] [PubMed]

3. Schwarz, D.; Kisselev, P.; Cascorbi, I.; Schunck, W.H.; Roots, I. Differential metabolism of benzo[a]pyrene and benzo[a]pyrene-7,8-dihydrodiol by human CYP1A1 variants. Carcinogenesis 2001, 22, 453-459. [CrossRef] [PubMed]

4. $\quad$ Osborne, M.R.; Brookes, P.; Beland, F.A.; Harvey, R.G. The reaction of ( \pm )-7 $\alpha, 8 \beta$-dihydroxy-9 $\beta, 10 \beta$-epoxy7,8,9,10-tetrahydrobenzo(a)pyrene with dna. Int. J. Cancer 1976, 18, 362-368. [CrossRef] [PubMed]

5. Boysen, G.; Hecht, S.S. Analysis of DNA and protein adducts of benzo[a]pyrene in human tissues using structure-specific methods. Mutat. Res. 2003, 543, 17-30. [CrossRef]

6. Rojas, M.; Marie, B.; Vignaud, J.M.; Martinet, N.; Siat, J.; Grosdidier, G.; Cascorbi, I.; Alexandrov, K. High DNA damage by benzo[a]pyrene 7,8-diol-9,10-epoxide in bronchial epithelial cells from patients with lung cancer: Comparison with lung parenchyma. Cancer Lett. 2004, 207, 157-163. [CrossRef]

7. Alexandrov, K.; Rojas, M.; Rolando, C. DNA damage by benzo(a)pyrene in human cells is increased by cigarette smoke and decreased by a filter containing rosemary extract, which lowers free radicals. Cancer Res. 2006, 66, 11938-11945. [CrossRef]

8. Pfeifer, G.; Yoon, J.H.; Liu, L.; Tommasi, S.; Wilczynski, S.P.; Dammann, R. Methylation of the RASSF1A gene in human cancers. Biol. Chem. 2002, 383, 907-914. [CrossRef]

9. Sporn, M.B.; Suh, N. Chemoprevention of cancer. Carcinogenesis 2000, 21, 525-530. [CrossRef]

10. Stoner, G.D.; Morse, M.A.; Kelloff, G.J. Perspectives in cancer chemoprevention. Environ. Health Perspect. 1997, 105, 945-954.

11. Guengerich, F.P.; Shimada, T. Activation of procarcinogens by human cytochrome P450 enzymes. Mutat. Res. 1998, 400, 201-213. [CrossRef]

12. Yang, C.S.; Smith, T.J.; Hong, J.Y. Cytochrome P-450 Enzymes as Targets for Chemoprevention against Chemical Carcinogenesis and Toxicity: Opportunities and Limitations. Cancer Res. 1994, 54, 1982s-1986s. [PubMed]

13. Scalbert, A.; Johnson, I.T.; Saltmarsh, M. Polyphenols: Antioxidants and beyond. Am. J. Clin. Nutr. 2005, 81, 215S-217S. [CrossRef] [PubMed]

14. Pandey, K.B.; Rizvi, S.I. Plant polyphenols as dietary antioxidants in human health and disease. Oxid. Med. Cell Longev. 2009, 2, 270-278. [CrossRef] [PubMed]

15. Zhang, H.; Tsao, R. Dietary polyphenols, oxidative stress and antioxidant and anti-inflammatory effects. Curr. Opin. Food Sci. 2016, 8, 33-42. [CrossRef]

16. Khan, N.; Mukhtar, H. Tea polyphenols for health promotion. Life Sci. 2007, 81, 519-533. [CrossRef] [PubMed]

17. Hessien, M.; El-Gendy, S.; Donia, T.; Sikkena, M.A. Growth inhibition of human non-small lung cancer cells h460 by green tea and ginger polyphenols. Anticancer Agents Med. Chem. 2012, 12, 383-390. [CrossRef] [PubMed]

18. Zhu, X.; Wetta, H. Genetics and epigenetics in tumorigenesis: Acting separately or linked. Austin J. Clin. Med. 2014, 1, 1016.

19. Barron, C.C.; Moore, J.; Tsakiridis, T.; Pickering, G.; Tsiani, E. Inhibition of human lung cancer cell proliferation and survival by wine. Cancer Cell. Int. 2014, 14, 6. [CrossRef]

20. Bauer, D.; Pimentel de Abreu, J.; Silva, H.S.; Goes-Neto, A.; Bello, M.G.; Teodoro, A.J. Antioxidant Activity and Cytotoxicity Effect of Cocoa Beans Subjected to Different Processing Conditions in Human Lung Carcinoma Cells. Oxid. Med. Cell. Longev. 2016, 2016, 7428515. [CrossRef] 
21. Rajendran, P.; Ekambaram, G.; Sakthisekaran, D. Cytoprotective Effect of Mangiferin on Benzo(a)pyrene-Induced Lung Carcinogenesis in Swiss Albino Mice. Basic Clin. Pharmacol. Toxicol. 2008, 103, 137-142. [CrossRef]

22. Fantini, M.; Benvenuto, M.; Masuelli, L.; Frajese, G.V.; Tresoldi, I.; Modesti, A.; Bei, R. In vitro and in vivo antitumoral effects of combinations of polyphenols, or polyphenols and anticancer drugs: Perspectives on cancer treatment. Int. J. Mol. Sci. 2015, 16, 9236-9282. [CrossRef] [PubMed]

23. Kou, X.; Han, L.; Li, X.; Xue, Z.; Zhou, F. Antioxidant and antitumor effects and immunomodulatory activities of crude and purified polyphenol extract from blueberries. Front. Chem. Sci. Eng. 2016, 10, 108-119. [CrossRef]

24. Amararathna, M.; Johnston, M.R.; Vasantha, H.P. Plant Polyphenols as Chemopreventive Agents for Lung Cancer. Int. J. Mol. Sci. 2016, 17, 1352. [CrossRef] [PubMed]

25. Simmons, T.; Andrianasolo, E.; McPhail, K.; Flatt, P.; Gerwick, W.H. Marine natural products as anticancer drugs. Mol. Cancer Ther. 2005, 4, 333-342. [PubMed]

26. Folmer, F.; Jaspars, M.; Dicato, M.; Diederich, M. Photosynthetic marine organisms as a source of anticancer compounds. Phytochem. Rev. 2010, 9, 557-579. [CrossRef]

27. Malve, H. Exploring the ocean for new drug developments: Marine pharmacology. J. Pharm. Bioallied. Sci. 2016, 8, 83-91. [CrossRef]

28. Rowley, D.C.; Hansen, M.S.; Rhodes, D.; Sotriffer, C.A.; Ni, H.; McCammon, J.A.; Bushman, F.D.; Fenical, W. Thalassiolins A-C: New marine-derived inhibitors of HIV cDNA integrase. Bioorg. Med. Chem. 2003, 10, 3619-3625. [CrossRef]

29. Kontiza, I.; Stavri, M.; Zloh, M.; Vagias, C.; Gibbons, S.; Roussis, V. New metabolites with antibacterial activity from the marine angiosperm Cymodocea nodosa. Tetrahedron 2008, 64, 1696-1702. [CrossRef]

30. Achamlale, S.; Rezzonico, B.; Grignon-Dubois, M. Evaluation of Zostera detritus as a potential new source of zosteric acid. J. Appl. Phycol. 2009, 21, 347-352. [CrossRef]

31. Carbone, M.; Gavagnin, M.; Mollo, E.; Bidello, M.; Roussis, V.; Cimino, G. Further syphonosides from the sea hare Syphonota geographica and the sea-grass Halophila stipulacea. Tetrahedron 2008, 64, 191-196. [CrossRef]

32. Hamdy, A.H.; Mettwally, W.S.; Abou El Fotouh, M.; Rodriguez, B.; El-Dewany, A.I.; El-Toumy, S.A.; Hussein, A.A. Bioactive Phenolic Compounds from the Egyptian Red Sea Seagrass Thalassodendron ciliatum. Z. Für Nat. C 2012, 67, 291-296. [CrossRef] [PubMed]

33. Regalado, E.L.; Rodríguez, M.; Menéndez, R.; Concepción, Á.A.; Nogueiras, C.; Laguna, A.; Rodríguez, A.A.; Williams, D.E.; Lorenzo-Luaces, P.; Valdés, O.; et al. Repair of UVB-damaged skin by the antioxidant sulphated flavone glycoside thalassiolin B isolated from the marine plant Thalassia testudinum Banks ex Konig. Mar Biotechnol. 2009, 11, 74-80. [CrossRef] [PubMed]

34. Regalado, E.L.; Menendez, R.; Valdés, O.; Morales, R.A.; Laguna, A.; Thomas, O.P.; Hernandez, Y.; Nogueiras, C.; Kijjoa, A. Phytochemical Analysis and Antioxidant Capacity of BM-21, a Bioactive Extract Rich in Polyphenolic Metabolites from the Sea Grass Thalassia testudinum. Nat. Prod. Commun. 2012, 7, 47-50. [CrossRef]

35. Rodeiro, I.; Donato, M.; Martinez, I.; Hernandez, I.; Garrido, G.; González-Lavaut, J.; Menendez, R.; Laguna, A.; Castell, J.V.; Gómez-Lechón, M.J. Potential hepatoprotective effects of new Cuban natural products in rat hepatocytes culture. Toxicol. In Vitro 2008, 22, 1242-1249. [CrossRef]

36. Garateix, A.; Salceda, E.; Menéndez, R.; Regalado, E.L.; López, O.; García, T.; Morales, R.A.; Laguna, A.; Thomas, O.P.; Soto, E. Antinociception produced by Thalassia testudinum extract BM-21 is mediated by the inhibition of acid sensing ionic channels by the phenolic compound thalassiolin B. Mol. Pain 2011, 7, 10. [CrossRef] [PubMed]

37. Rodeiro, I.; Hernández, I.; Herrera, J.A.; Riera, M.; Donato, M.T.; Tolosa, L.; González, K.; Ansoar, Y.; Gómez-Lechón, M.J.; Vanden Berghe, W.; et al. Assessment of the cytotoxic potential of an aqueous-ethanolic extract from Thalassia testudinum angiosperm marine grown in the Caribbean Sea. J. Pharm. Pharmacol. 2018, 70, 1553-1560. [CrossRef] [PubMed]

38. Rodeiro, I.; Gomez-Lechon, M.J.; Tolosa, L.; Pérez, G.; Hernández, I.; Menéndez, R.; Regalado, E.L.; Castell, J.V.; Donato, M.T. Modulation of biotransformation and elimination systems by BM-21, an aqueous ethanolic extract from Thalassia testudinum, and thalassiolin B on human hepatocytes. J. Funct. Foods 2012, 4, 167-176. [CrossRef] 
39. Miguel, V.; Otero, J.A.; Barrera, B.; Rodeiro, I.; Prieto, J.G.; Merino, G.; Álvarez, A.I. ABCG2/BCRP interaction with the sea grass Thalassia testudinum. Drug Metab. Pers. Ther. 2015, 30, 251-256. [CrossRef]

40. Rodeiro-Guerra, I.; Hernández-Ojeda, S.L.; Herrera-Isidrón, J.A.; Hernández-Balmaseda, I.; Padrón-Yaquis, S.; del Rosario Olguín-Reyes, S.; Alejo-Rodríguez, P.L.; Ronquillo-Sánchez, M.D.; Camacho-Carranza, R.; del Valle, R.M.; et al. Study of the interaction of an extract obtained from the marine plant Thalassia testudinum with pahse I metabolism in rats. Rev. Int. Contam. Ambient. 2017, 33, 547-557. [CrossRef]

41. Clementino, M.; Shi, X.; Zhang, Z. Prevention of Polyphenols against Carcinogenesis Induced by Environmental Carcinogens. J. Environ. Pathol. Toxicol. Oncol. 2017, 36, 87-98. [CrossRef]

42. Omidian, K.; Rafiei, H.; Bandy, B. Polyphenol inhibition of benzo[a]pyrene-induced oxidative stress and neoplastic transformation in an in vitro model of carcinogenesis. Food Chem. Toxicol. 2017, 106, 165-174. [CrossRef] [PubMed]

43. Shimada, T. Inhibition of Carcinogen-Activating Cytochrome P450 Enzymes by Xenobiotic Chemicals in Relation to Antimutagenicity and Anticarcinogenicity. Toxicol. Res. 2017, 33, 79-96. [CrossRef] [PubMed]

44. Chae, Y.H.; Marcus, C.E.; Ho, D.K.; Cassady, J.M.; Baird, W.M. Effects of synthetic and naturally occurring flavonoids on benzo[a]pyrene metabolism by hepatic microsomes prepared from rats treated with cytochrome P-450 inducers. Cancer Lett. 1991, 60, 15-24. [CrossRef]

45. De la Torre, E.; Rodeiro, I.; Menéndez, R.; Pérez, C.D. Thalassia testudinum, a sea plant with great therapeutical potentialities. Rev. Cubana Plant. Med. 2012, 17, 288-296.

46. Menéndez, R.; García, T.; Garateix, A.; Morales, R.A.; Regalado, E.L.; Laguna, A.; Valdés, O.; Fernández, M.D. Neuroprotective and antioxidant effects of Thalassia testudinum extract BM-21, against acrylamide-induced neurotoxicity in mice. J. Pharm. Pharmacogn. Res. 2014, 2, 53-62.

47. Arora, S. In vivo prediction of CYP-mediated metabolic interaction potential of formononetin and biochanin a using in vitro human and rat CYP450 inhibition data. Toxicol. Lett. 2015, 239, 1-8. [CrossRef]

48. Delgado-Roche, L.; Santes-Palacios, R.; Herrera, J.A.; Hernández, S.L.; Riera, M.; Fernández, M.D.; Mesta, F.; Garrido, G.; Rodeiro, I.; Espinosa-Aguirre, J.J. Regulation of Human Cytochrome P4501A1 (hCYP1A1): A Plausible Target for Chemoprevention? Biomed. Res. Int. 2016, 2016, 5341081.

49. Santes-Palacios, R.; Marroquín-Pérez, A.; Hernández-Ojeda, S.L.; Camacho-Carranza, R.; Govozensky, T.; Espinosa-Aguirre, J.J. Human CYP1A1 inhibition by flavonoids. Toxicol. In Vitro 2020, 62, 104681. [CrossRef]

50. Zhai, S.; Dai, R.; Friedman, F.K.; Vestal, R.E. Comparative inhibition of human cytochromes P450 $1 \mathrm{~A} 1$ and 1A2 by flavonoids. Drug Metab. Dispos. 1998, 26, 989-992.

51. Pastrakuljic, A.; Tang, B.K.; Roberts, E.A.; Kalow, W. Distinction of CYP1A1 and CYP1A2 activity by selective inhibition using fluvoxamine and isosafrole. Biochem. Pharmacol. 1997, 53, 531-538. [CrossRef]

52. Schwarz, D.; Roots, I. In vitro assessment of inhibition by natural polyphenols of metabolic activation of procarcinogens by human CYP1A1. Biochem. Biophys. Res. Commun. 2003, 303, 902-907. [CrossRef]

53. Sundberg, K.; Dreij, K.; Seidel, A.; Jernström, B. Glutathione conjugation and DNA adduct formation of dibenzo[a,1]pyrene and benzo[a]pyrene diol epoxides in V79 cells stably expressing different human glutathione transferases. Chem. Res. Toxicol. 2002, 15, 170-179. [CrossRef] [PubMed]

54. Alexandrov, K.; Cascorbi, I.; Rojas, M.; Bouvier, G.; Kriek, E.; Bartsch, H. CYP1A1 and GSTM1 genotypes affect benzo[a]pyrene DNA adducts in smokers' lung: Comparison with aromatic/hydrophobic adduct formation. Carcinogenesis 2002, 23, 1969-1977. [CrossRef] [PubMed]

55. Baird, W.; Mahadevan, B. Carcinogenic polycyclic aromatic hydrocarbon-DNA adducts and mechanism of action. Environ. Mol. Mutagen. 2005, 45, 106-114. [CrossRef]

56. Hodek, P.; Koblihová, J.; Kizek, R.; Frei, E.; Arlt, V.M.; Stivorobá, M. The relationship between DNA adduct formation by benzo[a]pyrene and expression of its activation enzyme cytochrome P450 1A1 in rat. Environ. Toxicol. Pharmacol. 2013, 36, 989-996. [CrossRef]

57. Maron, D.M.; Ames, B.N. Revised methods for the Salmonella mutagenicity test. Mutat. Res. 1983, 113, 173-215. [CrossRef]

58. Fernández, M.D.; Llanio, M.; Arteaga, F.; Dajas, F.; Echeverri, C.; Ferreira, M.; Hernández, I.; Cabrera, B.; Rodríguez, M.; Aneiros, A. Propiedades anti-inflamatoria-analgésica y antioxidante de una planta marina. Avicennia 2003, 16, 31-35.

59. Kamaraj, S.; Vinodhkumar, R.; Anandakumar, P.; Jagan, S.; Ramakrishnan, G.; Devaki, T. The effects of quercetin on antioxidant status and tumor markers in the lung and serum of mice treated with benzo(a)pyrene. Biol. Pharm. Bull. 2007, 30, 2268-2273. [CrossRef] 
60. Singh, H.P.; Batish, D.; Kohli, R.; Arora, K. Arsenic-induced root growth inhibition in mung bean (Phaseolus aureus Roxb.) is due to oxidative stress resulting from enhanced lipid peroxidation. Plant. Growth Regul. 2007, 53, 65-73. [CrossRef]

61. Nebert, D.W.; Shi, Z.; Gálvez-Peralta, M.; Uno, S.; Dragin, N. Oral benzo[a]pyrene: Understanding pharmacokinetics, detoxication, and consequences-Cyp1 knockout mouse lines as a paradigm. Mol. Pharmacol. 2013, 84, 304-313. [CrossRef]

62. Guo, Z.; Gillam, E.M.; Ohmori, S.; Tukey, R.H.; Guengerich, F.P. Expression of modified human cytochrome P450 1A1 in Escherichia coli: Effects of 5' substitution, stabilization, purification, spectral characterization, and catalytic properties. Arch. Biochem. Biophys. 1994, 312, 436-446. [CrossRef] [PubMed]

63. Guengerich, F.P.; Martin, M.V. Purification of cytochromes P450: Products of bacterial recombinant expression systems. Methods Mol. Biol. 2006, 320, 31-37. [PubMed]

64. Burke, M.D.; Thompson, S.; Weaver, R.J.; Wolf, C.R.; Mayer, R.T. Cytochrome P450 specificities of alkoxyresorufin O-dealkylation in human and rat liver. Biochem. Pharmacol. 1994, 48, 923-936. [CrossRef]

65. Ohkawa, H.; Ohishi, N.; Yagi, K. Assay for lipid peroxides in animal tissues by thiobarbituric acid reaction. Anal. Biochem. 1979, 95, 351-358. [CrossRef]

66. Sedlak, J.; Lindsay, R.H. Estimation of total, protein-bound, and nonprotein sulfhydryl groups in tissue with Ellman's reagent. Anal. Biochem. 1968, 25, 192-205. [CrossRef]

67. Hayashi, M.; Tice, R.R.; MacGregor, J.T.; Anderson, D.; Blakey, D.H.; Kirsh-Volders, M.; Oleson, F.B.; Pacchierotti, F.; Romagna, F.; Shimada, H.; et al. In vivo rodent erythrocyte micronucleus assay. Mutat. Res. 1994, 312, 293-304. [CrossRef]

Publisher's Note: MDPI stays neutral with regard to jurisdictional claims in published maps and institutional affiliations. 